\title{
РЕЛИГИОВЕДЕНИЕ
}

UDC 299.51

\section{Worship of Zhou The Pious son in Changshu County of Jiangsu Province, China: Official and popular aspects*}

\author{
R. V. Berezkin \\ Fudan University, \\ 220, Handan Road, Shanghai, 200433, China
}

For citation: Berezkin R. V. Worship of Zhou The Pious son in Changshu County of Jiangsu Province, China: Official and popular aspects. Vestnik of Saint Petersburg University. Philosophy and Conflict Studies, 2019, vol. 35, issue 2, pp. 369-377. https://doi.org/10.21638/spbu17.2019.212

Changshu county of Jiangsu province in China (now under the jurisdiction of Suzhou city) is noteworthy for the cults of local deities that can be traced to the Song (960-1279) and Yuan (1260-1368) periods. They are still thriving in this area. The cult of Deity Zhou (Zhou shen) or Pious Son Zhou (Zhou xiaozi) is very important, as it was shared by the elite and common folk in the late imperial period (14-19 th $^{\text {ch }}$ centuries). However, while the elite emphasized the role of Zhou as a paragon of filial piety in the tradition of Confucian thought, commoners worshipped him mainly as the deity-protector, known for his miraculous responses to their prayers, which was very characteristic of Chinese folk beliefs on the whole. One form of elite and commoner cooperation was various temple activities held for deity Zhou during the Ming (1368-1644) and Qing (1644-1911) dynasties. In this article, the author compares various literary materials concerning the Zhou's beliefs, with the aim of demonstrating differences between elite and popular interpretations of this deity, as well as to analyze the evolution and continuity of Zhou's beliefs in Changshu over the course of several centuries. Materials used here mainly were obtained by the author during fieldwork in Changshu in 2011-2015 as well as in Shanghai libraries. Many folklore and epigraphic materials collected by the author are unique. They have not yet been published even in China and are analyzed here for the first time.

Keywords: Chinese folk beliefs, local deities, Chinese folklore, precious scrolls, temple festivals.

* This research was supported by the grant from the State Social Sciences Foundation of China "Survey and Cross-Disciplinary Research on Folk Beliefs Related Arts of the Taihu Lake Region", no. 17ZDA167. 本文为国家社会科学基金重大项目“太湖流域民间信仰类文艺资源的调查和跨学科研究” (批准号 17ZDA167）阶段性成果之一. The author also expresses his gratitude to Yu Yongliang, Xia Genyuan, Yu Dingjun, and Dou Heng for providing materials and assistance during fieldtrips.

(c) Санкт-Петербургский государственный университет, 2019 
Zhou the Pious Son, who was a local tutelary deity of Changshu county for several centuries, is believed to be a historical person who lived around the end of the $12^{\text {th }}$ century and was known for filial piety. In the $13^{\text {th }}$ century Zhou's cult was already promoted by the local elite, and in the $14^{\text {th }}$ century it entered the Imperial registers of sacrifices. At the same time he enjoyed popularity among commoners and is still widely worshipped in Changshu.

Several scholars have already paid attention to this cult $[1$, p. 44-49; 2, p. 174-186; 3 , p. 74-76]. However, materials they used were limited, as they mostly relied on local histories (gazetteers) and epigraphy, also preserved in the local historical sources. However, Pious Son Zhou is also featured in folk literature of the Changshu area, namely in baojuan (precious scrolls) texts that are recited at folk religious assemblies [4, p.67-76; 5, p. 384$400 ; 6 ; 7]$. In this paper I carry out comparison of different literary materials concerning the Zhou's beliefs to demonstrate the difference between elite and popular interpretations of this deity.

\section{The origins of Deity Zhou}

The earliest record about deity Zhou can be found in The Newly Revised Gazetteer of Qinchuan (Chongxiu Qinchuan zhi), compiled by Sun Yingshi (1154-1206) in 1196 and revised by Bao Lian and Lu Zhen in 1254 and 1363 respectively, which is the earliest available gazetteer of Changshu county $[8 \text {, juan } 10, \mathrm{p} .1245]^{1}$. It says that "the deity's original name was Zhou Rong, and while he was alive, he served his mother with utmost filial piety". After he died, he appeared to his mother in a dream and reported: "I have already become a deity, I must serve with utmost loyalty to the court and also perform my duty in the native place". At the beginning of Chunyou reign period of the Song dynasty (1241-1252), a local person and jinshi (Advanced scholar) ${ }^{2}$ Chen Quanbo built an altar to Zhou. Later, the monk Yaoguan initiated the construction of adjacent inner quarters, so that images of the deity's parents also were worshipped in his temple ${ }^{3}$. In the $12^{\text {th }}$ year of Chunyou reign (1252), jinshi Zhao Bifu and others reported miracles of this deity to the court, and the emperor donated a placard to his temple. This record tells that the worship of pious son Zhou was established in Changshu already during the Southern Song period (1127-1279). The deification of this person was based on his apparition to his mother, where he claimed to serve the court as well as his countrymen after his death. Thus, he became a person distinguished by both filial piety and loyalty to his monarch, which were the basic virtues of a subject in traditional Confucian thought.

With the support of the local literati Zhou's cult obtained official status through recognition of the imperial court. Local histories claim that in 1252 Zhou was awarded the title of Count of Miraculous Mercy (Linghui hou), inscribed on the temple placard. This was a common practice in the Song period, as literati often appealed for official titles for other local deities [10; 11, p. 445-490]. At the same time the Zhou's cult enjoyed popularity among commoners since the early period. For example, one of the earliest extant stele inscriptions of Zhou's temple, "Zhou xiaozi miao bei" by Qian Tong (ca. 1389), reads that at that time "people of Qinchuan worshipped the deity same as they served their parents. All the time of

${ }^{1}$ Qinchuan was the old name of Changshu during the Song dynasty.

2 The degree given at the highest level of state examinations.

3 There is the similar record about Zhou's worship in the Gazetteer of Suzhou Prefecture (Suzhou fu zhi 蘇州府志, 1379) [9, vol. 2, juan 15, 590]. 
the year there were many believers in the temple, so it was crowded as a market" [12, juan 6, p.22b]. The reason for this was "miraculous response" on the part of the deity that often was a decisive factor for a deity cult's growth in China [13; 14]. According to Qian Tong, "whenever there was a disaster of drought, flood or epidemics, those who cannot withstand it, prayed to the deity, and it always responded to their prayers" [12, juan 6, p. 22b].

Miracles performed by the deity by 1252 were listed in the literati's petition, which was later carved on the stele placed at the Zhou temple in the county seat. It contained records of six major occasions on which the deity performed miracles, including a flood, locust invasion, bandit attacks, transportation of military supplies and grain tributes, and epidemics [15, juan 15, p. 337]. The latter medicinal function of the deity obviously had a special place in commoners' lives. As Qian Tong's inscription testifies, by the $14^{\text {th }}$ century, locals often prayed to Zhou for the cure of illnesses. The leaves of the zisu plant (Perilla nankinensis Decne), distributed in his temple, were believed to heal different diseases. According to Qian Tong, the deity's mother was cured by this medicine, and so it was collected in the temple and "was piled like mountains" [12, juan 6, p.22b].

Therefore, in the 13-14 ${ }^{\text {th }}$ centuries Pious Son Zhou's cult already attracted the attention of different social groups in Changshu and was a classical example of Chinese "popular religion," which is closely related to daily life of local society and includes deities and practices of various origins [16, p. 499-502]. All these groups contributed to the development of Zhou's cult in the later period.

\section{Evolution of Zhou's beliefs}

Elite and official support for Zhou's cult continued during the Ming and Qing dynasties. In 1371 the Pious Son Zhou was included into the official "registers of sacrifices" that regulated the worship of deities in the Empire [9, vol. 2, juan 15, p. 590]. Thus, county officials were required to worship Zhou once a year, on the twenty-first day of the ninth month. Still, the temple for Zhou in the county city was re-built with the support of local people at the beginning of the Ming dynasty, as testified in the record of its renovation by Lin Datong (late $14-$ early $15^{\text {th }}$ century) [17, juan 12, p. 26a-26b]. It was continuously renovated during the Ming and Qing dynasties by the county magistrates.

This is a rare case of the early inclusion of a local deity of Changshu into official sacrificial registers. Many popular deities, worshipped in Changshu, never received such status. Why was Zhou included? Apparently, his original status of the paragon of filial piety attracted the Confucian elite in the county and central government and his worship was thought to be beneficial for local customs. For example, Qian Tong's text emphasizes the filial piety and loyalty of Zhou Rong, which are the basic Confucian virtues. Thus, he could serve as a paragon for later generations [12, juan 6, p. 23a].

At the same time, in addition to its official status, Zhou's cult still had many popular aspects that made him attractive for both elite and commoners during the Ming and Qing dynasties. Many worshippers established personal connections with the deity, as they prayed for the health of family members [12, juan 13, p. 13a-14b]. Prayers to Zhou included divination and communication through medium séances, which were practiced by both elite and commoners. The inscription about the ritual land of the temple, "Zhou Xiaozi shen dan jiao tian ji" by Qian Shijun (dated 1625) says: "The special shrine for this deity is located to the south-east of the county seat. His 'travel palaces' are also numerous 
in streets in other places. Even the commoners' families treat the deity with offerings, so that the incense burning does not cease at the temples day and night. Both gentlemen and commoners pray to the deity, when they get ill. If there are disasters, they will certainly ask for his protection. Those who raise suspicions always go to ask about good and bad luck through divination" [12, juan 13, p. 18b]. Divination practices are also mentioned in other elite written sources of the $15-16^{\text {th }}$ centuries [2, p. 179].

The stele inscription in the town of Tangshi, which was thought to be the native place of Zhou Rong (he was born in the nearby village of Shize, or the modern village of Shixin) by the famous scholar-politician of the Ming dynasty Zhang Cai (1596-1648), a native of the nearby Taicang county, gives a vivid picture of the deity's cult at the beginning of the $17^{\text {th }}$ century: "Every time there is a drought or flood in the ward, they pray for the deity's response with the sacred chants, and perform sacrifices, they also make oath in front of the deity [when they pray for progeny], and when the son is born, they give him the deity's surname" [12, juan 6, p.45a]. Unfortunately, this inscription does not specify who performed these rites, Daoists or local mediums. This practice of consecrating a newborn baby to the local protective deity was widespread until recently in Changshu, although other popular deities usually figured as divine guardians [4, p. 75-76].

As the local histories testify, at the end of the $19^{\text {th }}$ century and into the beginning of the $20^{\text {th }}$ century, there were several temples for Deity Zhou in towns and villages of the Changshu county. According to the Combined Gazetteer of Changshu and Zhaowen (first printed in 1904), three annual sacrifices for Zhou were performed in his temple in Changshu county city [15, juan 15, p. 338]. Qian Zhonglian (1908-2003), a scholar of Chinese literature and native of Changshu, wrote that at the middle of the eighth month there was a special festival when Zhou's image was taken to his parents' tomb outside the city [18, p. 280]. The temple festival for Zhou in Tangshi around the tenth of the fourth month every year also attracted numerous believers [18, p. 274]. All these temple activities stopped in the $20^{\text {th }}$ century. Still, several temples for Zhou exist now. The old temples in Tangshi and Shize, though destroyed during the Cultural Revolution, were rebuilt recently, and Daoist rites are still held there.

Official and elite support for Zhou's cult stands for the co-operation of officials and local gentry in promotion of cults and values representing imperial state orthodoxy (NeoConfucianism). This has been emphasized in several Western theories concerning Chinese religion. The American scholar Prasenjit Duara has demonstrated the use of the Guandi's (Guan Yu's) cult by the state and local elites in promotion of the "correct" values, which he called "superscription of symbols" [19]. However, in the case of Deity Zhou the situation is too complex to be described simply as "superscription." First, this cult underwent an interesting evolution. It presumably originated as the usual paragon of filial piety, but then grew out of its standard form: the filial son turned into the local tutelary deity. Various beliefs and practices, and often those of quite deviant origin (sorcery, divination, and mediumistic healing), existed under the official mask of the Pious Son. Scholars-officials tolerated them, which was normal for popular religious practices in late imperial China.

However, not all learned gentlemen were content with the popularity of Zhou's cult. One can find traces of scholarly polemics about the propriety of this cult in elite writings. Zhang Cai started his stele inscription for Zhou with by refuting the critical attitude of other scholars who doubted that a filial son must be venerated as a deity [12, juan 6, p.45a]. Here we find an interesting juxtaposition of Deity Zhou with Confucian he- 
roes known for their filial piety, such as the legendary Emperor Shun, King Wen of Zhou ( $12^{\text {th }}$ century BCE) and Zeng Shen (505-435 BCE). Zhang Cai insisted on the necessity of such a cult as Zhou's, although it is different from the traditional Confucian cults of pious sons. He regarded it as the representation of the "Way of gods" used by the ruler but not fully comprehensible to the people. Thus, it is different from the "Way of humans" that includes secularized worship of paragons of Confucian virtues: "As for the [Confucian] teachers, they have established the Way of humans to govern people openly, on the top and at the bottom, and everywhere they make the spirit of all things. As for the deities, they have established the Way of gods to govern people indirectly" [12, juan 6, p.45a]. Here Zhang Cai obviously hinted at the developed religious aspects of Zhou's cult (that he describes below). In his view, this cult was useful for local administrators because it was beneficial for commoners' customs. He advocated the use of Zhou's cult for political ends, a view shared by governors of Changshu county.

\section{Hagiographies of deity Zhou}

As noted above, epigraphy constitutes important material for the reconstructing the history of Zhou's cult. There are many epigraphic materials about Deity Zhou from Changshu, which one can explain by the literati-officials' support for this cult. I have information about eighteen steles dating to the period between 1389 and 1805. Although not all of them have been preserved, these stele inscriptions provide a picture of continuous development of the cult, although they do not discuss in detail the earthly life of Zhou Rong. They concentrate on miracles performed by the deity instead [12, juan 6, p.32a, juan 13, p. 10a-11b].

At the same time, new details were added to Zhou's biography in the local history Changshu xianzhi, edited by Yang Ziqi and Sang Yu (end of the $15^{\text {th }}$ century); later it became the subject of local folklore. It tells how Zhou Rong divorced his wife because of her disrespectful behavior towards his mother. It says: "Rong lost his father at an early age, and he served his mother with utmost filial piety. $<\ldots>$ He served in the county seat, but once he went on duty to Dingshan, where he obtained several chestnuts. He chose the beautiful and big ones and prepared them to be served to his mother, while he left the small and common ones for his wife. His wife hid the beautiful and big chestnuts, while presented the small ones to his mother, and the mother took them out to eat [in the Rong's presence]. Rong raised suspicion in his heart, as he found out that his wife was not a filial woman. He divorced her on other pretext, and people till now praise him as Zhou the Filial Son" [20, juan 4, p. 56b].

This story is also briefly mentioned in another piece of literati's writing, "A Discourse on Pious Son Zhou of the Song Dynasty" by Shen Yue (1510) [12, juan 15, p.4a-5a]. It praises Zhou's attitude towards his wife, which would be typical of Neo-Confucian thinkers. Therefore, this story was well-known to the literati since the $15-16^{\text {th }}$ centuries. However, only in the baojuan texts I was able to find the developed form of this story.

The Baojuan of Deity Zhou is still popular among the local performers (local name: "masters of telling scriptures") in several areas of Changshu and Zhangjiagang ${ }^{4}$. These performances can be traced to Buddhist preaching practices, and several baojuan texts in

${ }^{4}$ The southern part of the modern Zhangjiagang city area had belonged to Changshu county, before the separate county of Shazhou 沙州 was established there in 1962. 
Changshu still deal with the Buddhist deities; however, many texts are about local deities such as Zhou. The Baojuan of Deity Zhou is often performed during religious assemblies at believers' houses (private assemblies) and during temple festivals $[21]^{5}$. The text I mainly use here is a manuscript (1990) by Xia Genyuan, a performer in the Fenghuang town of Zhangjiagang (b. 1945). Xia Genyuan studied telling scriptures under Qian Xiaoyan (b. 1932), who started to perform it before the establishment of the PRC in 1949 [22, vol. 2, p. 1472-1473]. He mainly copied his texts from the manuscripts of Qian Xiaoyan. Unfortunately, it is hard to determine the exact date of the original text. I also consulted another recension of the same text by Yu Dingjun (b.1942), a master of scriptures from Liantang town in Changshu, based on a manuscript copied by his brother Yu Baojun in 1991 [23, vol. 2, p. 687-695]. His brother likely copied it from a manuscript of older performers, when he revived the family tradition of telling scriptures. Both recensions have much in common.

The Baojuan of Deity Zhou is noteworthy for scholars of Chinese folk beliefs. First, it retains many elements of the Pious Son's hagiography formed during the late imperial period as attested in the historical sources. The story of divorce, central in this text, also could be influenced by written sources, such as the local gazetteers. However, it is much more detailed than local histories and has a repetitive structure: Zhou Rong's wife not only steals the fruit of immortality that Zhou Rong obtained for his mother in the Buddhist monastery, but she also surreptitiously eats the fish and chicken that Zhou Rong bought for his mother.

Furthermore, the hagiography of Zhou Rong in baojuan is developed with the use of fantastic details that do not exist in other sources. For example, Zhou Rong defeated enemies and repaired the dam on the Huanghe with the use of his supernatural powers. This is obviously local folklore, as one find similar stories in baojuan dealing with other popular deities of Changshu. The punishment of the Zhou's wife, who after the divorce turned into a night bird, is also a widespread folklore motif that also appears in other baojuan in Changshu [24, p. 101-102]. In the context of telling scriptures it is also related to the Buddhist ideas of rebirth and retribution.

Thus, Baojuan of Deity Zhou deals with the extraordinary life of a deified hero rather than his posthumous miracles, which is the difference between baojuan and stele texts. As the baojuan text contains the vernacular hagiography of the deity recited to illiterate commoners, several details point to its main target audience: peasants. It presents Zhou Rong's father as a country squire rather than a petty official, as in the literati's writings. Although the was rich and opened a pawnshop, he was nice to poor countrymen. His family had to cope with draught and flood, natural disasters that peasants often faced. Significantly, the Xia's recension of Baojuan of Deity Zhou presents these disasters as the result of the emperor's misgovernment, which also is a sign of popular interpretation of historical events [25, p.3]. Therefore, this text obviously creates the image of Deity Zhou that is very close to the peasant audience of baojuan and fits the special functions of this cult in the rural areas in the later period. Furthermore, the text is written in a mixture of classical Chinese, northern vernacular, and local dialect of Changshu (belonging to the Wu group of Chinese dialects). Baojuan of Deity Zhou is performed with the local pronunciation, and the performers can elaborate on the basic story in the script, which makes the performance comprehensible and appealing to the local folk audience.

${ }^{5}$ Here I do not describe organization and manner of these performances. 


\section{Conclusion}

Different materials on the deity Zhou's cult from the Changshu area demonstrate its different aspects. They often complement each other, as they present different images of the deity and different kinds of its activities. While elite texts emphasize Confucian virtues of Zhou Rong and miracles performed by this deified figure after death, baojuan texts present the developed vernacular hagiography of this deity. Although some details of this hagiography in baojuan can be traced back to the written sources of the Ming dynasty, there are many fantastic and folk elements not to be found in the elite works.

Although Zhou's cult in Changshu was promulgated by local elites and officially approved by the state since the $13-14^{\text {th }}$ centuries, popular aspects of this cult, such as prognostications, granting children and curative function, were always present in the local worship activities. Officials and elite tolerated them and even participated in the worship, as attested in the surviving epigraphy.

Legends concerning Zhou have been transmitted in the oral form through recitation of the baojuan texts. This explains why this cult could outlive the late imperial state and survived during anti-religious campaigns. While official support for this cult ended with the collapse of the imperial system in 1912, and major temple festivals for Zhou disappeared in the 1950s, baojuan texts have been performed during religious gatherings in the temples and believers' homes until the present. Today popular baojuan storytelling still remains a major way of transmission of beliefs among the local people.

\section{References}

1. Hamashima Atsutoshi (2008), Ming Qing Jiangnan nongcun shehui yu minjian xinyang [Rural society and folk beliefs of Yangtze Valley during the Ming and Qing dynasties], Chin. transl. by Zhu Haibin, Xiamen daxue chubanshe, Xiamen. (In Chinese)

2. Wang Jian (2010), Li hai xiang guan: Ming Qing yilai Jiangnan Su-Song diqu minjian xinyang yanjiu [Profit and harm inseparable: research on the folk beliefs in the Suzhou and Songjiang areas of Yangtze Valley since the Ming and Qing dynasties], Shanghai renmin chubanshe, Shanghai. (In Chinese)

3. Zhu Haibin (2008), Jisi zhengce yu minjian xinyang bianqian: Jinshi Zhejiang minjian xinyang yanjiu [Regulations of sacrifices and transformation of the folk beliefs: folk beliefs of Zhejiang province in the early modern period], Fudan daxue chubanshe, Shanghai. (In Chinese)

4. Yu Yongliang (1997), "Heyang baojuan diaocha baogao" [Report on the survey of baojuan in Heyang], in Minsu quyi [Journal of Chinese Theatre and Folklore], no. 110, pp. 67-88. (In Chinese)

5. Che Xilun (2009), Zhongguo baojuan yanjiu [Research on Chinese baojuan], Guangxi shifan daxue chubanshe, Guilin. (In Chinese)

6. Qiu Huiying (2010), "Jiangsu Changshu Baimao diqu xuanjuan huodong diaocha baogao"[Report on the survey of scroll recitation activities in the Baimao area, Changshu, Jiangsu], in Minsu quyi [Journal of Chinese Theatre and Folklore], no. 169, pp. 183-247. (In Chinese)

7. Yu Dingjun (2012), "Jiangsu Changshu de jiangjing xuanjuan" [Telling scriptures and scroll recitation in Changshu, Jiangsu], in Mazu yu minjian xinyang yanjiu tongxun [Bulletin of research on Mazu and other folk beliefs], no. 2, pp. 49-114. (In Chinese)

8. Sun Yingshi, et al. (eds) (1990), Qinchuan zhi [Gazetteer of Qinchuan], rpt. in Song-Yuan fangzhi congkan [Collection of gazetteers of the Song and Yuan dynasties], Zhonghua shuju, Beijing, vol. 2, pp. 11471309. (In Chinese)

9. Lu Xiong (ed.) (1974), Suzhou fu zhi [Gazetteer of Suzhou Prefecture], rpt. in Zhongguo fangzhi congshu: Huazhong difang [Collection of gazetteers: Central China], Chengwen chubanshe, Taibei, vol. 135, pts. 1-5. (In Chinese)

10. Hansen, V.(1990), Changing Gods in Medieval China, 1127-1276, Princeton University Press, Princeton, USA.

11. Zel'nitskiy A. D. (2012), “Ofitsial'naia ideologiia i populiarnye verovaniia” [Official ideology and popular beliefs], in Kravtsova, M.E. (ed.), in Protsess formirovaniia ofitsialnoi ideologii imperskogo Kitaya 
[Process of formation of official ideology in imperial China], Nauka Publ., St. Petersburg, pp. 445-490. (In Russian)

12. Shao Songnian (ed.) (1905), Haiyu wen zheng [Collected writings from Haiyu], in 10 vols., Hongwen shuju, [no place]. (In Chinese)

13. Sangren, S. P. (1987), History and Magical Power in a Chinese Community, Stanford University Press, Stanford, USA.

14. Hymes, R. (2002), Way and Byway: Taoism, Local Religion, and Models of Divinity in Sung and Modern China, University of California Press, Berkeley, USA.

15. Pang Hongwen (1974), Chongxiu Chang-Zhao hezhi gao [Revised combined gazetteer of Changshu and Zhaowen counties], rpt. in Zhongguo fangzhi congshu: Huazhong difang [Collection of gazetteers: Central China], Chengwen chubanshe, Taibei, vol. 153, pts. 1-5. (In Chinese)

16. Kravtsova M.E. (2004), Istoriia iskusstva Kitaia [History of Chinese Art], Lan` Publ., Krasnodar; Moscow. (In Russian)

17. Lin Datong (undated), Fanxuan ji [Collection of Fanxuan's writings], manuscript of the beginning of the $20^{\text {th }}$ century in Shanghai City Library, rare books division, no. 792860-67.

18. Qian Zhonglian (1992), Changshu zhang gu [Recollections of Changshu], Jiangsu lishi ziliao huibianbu, Nanjing. (In Chinese)

19. Duara, P. (1988), "Superscribing symbols: The Myth of Guandi, Chinese God of War", in Journal of Asian Studies, no. 47, vol. 4, pp. 778-795.

20. Yang Ziqi and Sang Yu (eds) (1499), Changshu xian zhi [Gazetteer of Changshu county], woodblock edition of 1499 (Toyo bunko Library, Tokyo).

21. Berezkin, R. (2013), "On the Survival of the Traditional Ritualized Performance Art in Modern China: A Case of Telling Scriptures by Yu Dingjun in Shanghu Town Area of Changshu City in Jiangsu Province," in Minsu quyi [Journal of Chinese Theatre and Folklore], no. 181, pp. 103-156.

22. Zhongguo Heyang baojuan ji [Collection of baojuan from Heyang in China] (2007), Shanghai wenhua chubanshe, vol. 1-2, Shanghai.

23. Zhongguo Changshu baojuan ji [Collection of baojuan from Changshu in China] (2015), Guwuxuan chubanshe, vol. 1-3, Suzhou.

24. Berezkin, R. (2013), “The Connection Between the Cults of Local Deities and Baojuan in Changshu county of Jiangsu," in Monumenta Serica, no. 61, pp. 73-106.

25. [Anonymous], Zhou shen baojuan [Baojuan of Deity Zhou] (1990), manuscript by Xia Genyuan.

Received: October 4, 2018

Accepted: February 7, 2019

Author's information:

Rostislav V. Berezkin — PhD, Senior Research Fellow; berezkine56@yandex.ru

\title{
Культ почтительного сына Чжоу в уезде Чаншу провинции Цзянсу в Китае: официальные и народные аспекты ${ }^{\star}$
}

\author{
Р. В. Березкин \\ Фуданьский университет, Научный институт гуманитарных исследований, \\ Китай, 200433, Шанхай, Ханьданьский пр., 220
}

Для цитирования: Berezkin R. V. Worship of Zhou The Pious son in Changshu County of Jiangsu Province, China: Official and popular aspects // Вестник Санкт-Петербургского университета. Фи-лософия и конфликтология. 2019. Т. 35. Вып. 2. С. 369-377. https://doi.org/10.21638/spbu17.2019.212 (In English)

* Статья подготовлена при поддержке гранта Государственного фонда исследований общественных наук КНР «Междисциплинарное исследование литературных материалов, относящихся к народным обычаям района озера Тайху», № 17ZDA167. 本文为国家社会科学基金重大项目“太湖 流域民间信仰类文艺资源的调查和跨学科研究”（批准号17ZDA167）阶段性成果之一. Автор выражает благодарность Юй Юнляну, Ся Гэнюаню, Юй Динцзюню и Доу Хэну за помощь с материалами и организацией полевых исследований. 
В бывшем уезде Чаншу провинции Цзянсу в Китае (в настоящее время в юрисдикции города Сучжоу) широкое распространение получили культы местных божеств, многие из которых восходят к династиям Сун (960-1279) и Юань (1260-1368). Некоторые из них сохранились в этой местности до настоящего времени. Культ божества Чжоу (Чжоу шэнь, или почтительного сына Чжоу - Чжоу сяоцзы) один из важнейших среди них, и он был общим для элиты и простолюдинов в позднеимперский период (XIVXIX вв.). Представители ученого сословия рассматривали его как образец сыновней почтительности в рамках конфуцианской идеологии, но простолюдины часто воспринимали его как местное божество-покровителя, известное своими чудесами, что было характерной чертой китайской народной религии. Взаимодействие разных групп населения часто выражалось в форме различных храмовых мероприятий, регулярно проводившихся в периоды Мин (1368-1644) и Цин (1644-1911). В статье проводится сравнительный анализ различных письменных материалов, относящихся к культу этого божества, таких как местные исторические источники, храмовая эпиграфика, заметки местных ученых и фольклор, с целью анализа различий между элитарными и простонародными интерпретациями популярного местного божества в Китае, а также с целью объяснения эволюции этого культа и его сохранения в настоящее время. Большинство материалов, использованных в работе, было собрано во время полевых исследований в Чаншу в 2011-2015 гг., а также в библиотеках Шанхая. В их числе редкие и уникальные фольклорные и эпиграфические материалы, еще не опубликованные даже в Китае и впервые введенные здесь в научный оборот.

Ключевые слова: китайские народные верования, местные божества, китайский фольклор, драгоценные свитки, храмовые праздники.

Статья поступила в редакцию 4 октября 2018 г;; рекомендована в печать 7 февраля 2019 г.

Контактная информация:

Березкин Ростислав Владимирович - канд. филол. наук, ст. науч. сотр.; berezkine56@yandex.ru 